\title{
Geometry and Construction at Cartagena de Indias Baseball Stadium's Thin Shell Roofs (Colombia, 1947)
}

\author{
Jorge Galindo Díaz ${ }^{1} \cdot$ Hernando Vargas Caicedo²
}

Published online: 5 December 2016

(C) Kim Williams Books, Turin 2016

\begin{abstract}
Concrete and reinforced-brick shells were introduced and actively developed in Colombia during the 1940s and 1950s. Formal, technical approaches were adapted to the regional context. In this paper, new materials are proposed for analysis in the particularly light roof designs by Guillermo González Zuleta (1916-1995) as a part of a larger Colombian building collection on thin membranes from that period. In 1947, González Zuleta, a consulting and building engineer, developed stands and roofing for the baseball stadium in Cartagena, Colombia using $16.59 \mathrm{~m}$ long cantilevers that supported $5 \mathrm{~cm}$ thick vaulted shells. His design has received international recognition since 1948 . The vaults are supported by a set of 12 concrete frames resulting from a rational geometrical layout that operates as the basic design and dimensional tool. The resulting structure effectively responds to mechanical and spatial criteria and is appropriately adapted to the local climate and resources.
\end{abstract}

Keywords Design analysis · Parabolas - Shells in reinforced masonry shells · Tracing systems

Jorge Galindo Díaz

jagalindod@unal.edu.co

Hernando Vargas Caicedo

hvargas@uniandes.es

1 School of Architecture and Urbanism, Universidad Nacional de Colombia, Manizales, Colombia

2 Department of Civil and Environmental Engineering, Universidad de los Andes, Bogotá, Colombia 


\section{Introduction}

In the July 1948 issue of Architectural Record, ${ }^{1}$ a project entirely designed and built by Colombian professionals was published for the first time. The newly built Cartagena de Indias baseball stadium was noted for the structural audacity of its curved reinforced concrete frames and especially for the use of soft bi-dimensionally arched thin membranes, which hovered above the stadium stands in a hot humid tropical environment.

The project resulted from a long technological appropriation process on reinforced concrete conditions and forms initiated in Colombia, starting in the early twentieth century with small scale buildings such as Quiosco de la Luz (1910), Molino La Unión (1912) and Faenza Theatre (1924), in Bogota, along with Mogollón at Cartagena de Indias (1927). Manizales Cathedral (1928-1939) was a large concrete construction built in response to the frequent fires in Manizales that often destroyed its wooden buildings (Vargas and Galindo 2015).

Until 1939 most Portland cement was still being imported when three local plants united to promote its use, publishing international projects and advertising reinforced concrete for new luminous, hygienic, strong and durable buildings (Vargas and Ortega 2008). Additionally, an increased professional interest in calculation and building methods developed as evidenced by technical articles published since 1939 in the Universidad Nacional engineering and architecture school's Ingeniería y Arquitectura magazine. In 1941 two students presented a paper describing simplified calculation methods for hollow clay slabs (Paredes and Garzón 1941) and a 1942 article (Bonelly 1942) contributed practical formulae for fast membrane design. In 1944, new analytical methods were derived from solutions by Finsterwalder and Dishinger (Cornelissen 1944). Additionally, Universidad Nacional Materials Laboratory reports appeared frequently in periodicals comparing local concrete strengths with US cases (Guerra 1941a, b).

The first practical results from this academic effort appeared when German architect Leopoldo Rother (1894-1978) designed the new concrete University stadium for its modern campus, covering its stands with concrete slabs. In 1946 he started his design for the Girardot market hall using thin reinforced masonry membrane shells for the first time in Colombia. This building, dedicated in 1954, covers shops with 198 shells $7 \mathrm{~m}$ long and $2.5 \mathrm{~m}$ wide by using $5 \mathrm{~cm}$ thin shells. This large surface acts as noble shading allowing cross ventilation by supporting the roof on $\mathrm{V}$ concrete columns in a hot and humid local climate (Fig. 1).

\footnotetext{
${ }^{1}$ After the Architectural Record (1948) issue, Cartagena Stadium was published in Informes de la Construcción (1949); this project was included in European publications such as Cassi Ramelli (1950) and Zietzschmann (1952).
} 


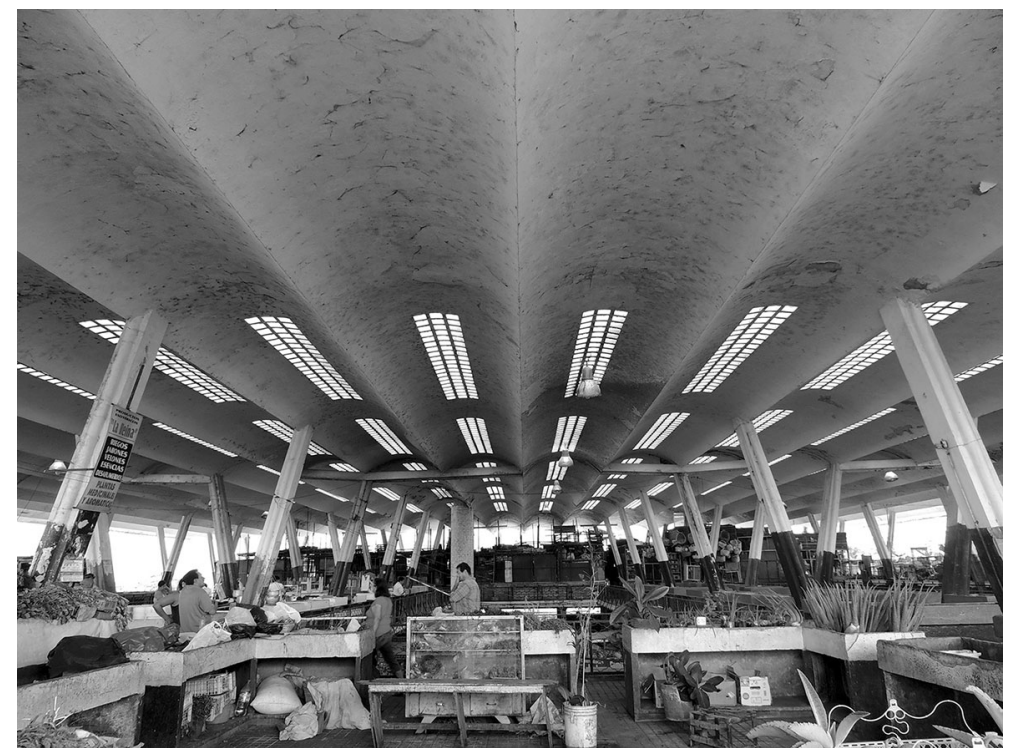

Fig. 1 Shells in reinforced masonry in Rother Girardot market hall (1946). Photography by the authors

\section{Cartagena de Indias Baseball Stadium}

\section{General Description of the Project}

As part of a sports compound for the World Amateur Baseball Series and National Games, the baseball stadium was developed by the National Buildings Directorate, where the engineer Guillermo González Zuleta (Universidad Nacional of Colombia, 1940) was one of the heads. Supporting the architectural team formed by Alvaro Ortega (Harvard University, 1945), Gabriel Solano (University of Pennsylvania, 1944 and Harvard University, 1945), Jorge Gaitán Cortés (Yale University, 1944) and Edgar Burbano (Universidad Nacional of Colombia, 1946), González Zuleta was in charge of structural design and the group of Alfonso Mejía, Mario Barahona, Julio Montenegro and Ramón Peñaranda took the construction responsibilities. Design and building took 6 months under the pressing Games deadline in 1947.

The main design challenge was to cover the stands without intermediate supports in order to provide unobstructed visibility to the audience. To accomplish this a three-dimensional plan with curved elements was developed, confronting technical and building constraints and forming a strongly appealing building that is best appreciated from the baseball field (Arango 1989).

The stadium includes three stands along the baseball diamond corners. The central part is covered and exposes the main architectural and structural contribution. In plan, the right angle is softened through its arching. Twelve curved C-frames supported on two columns and spaced at $10.5 \mathrm{~m}$, form the structure on which rest stands for 8000 people and the canopy (Fig. 2). 


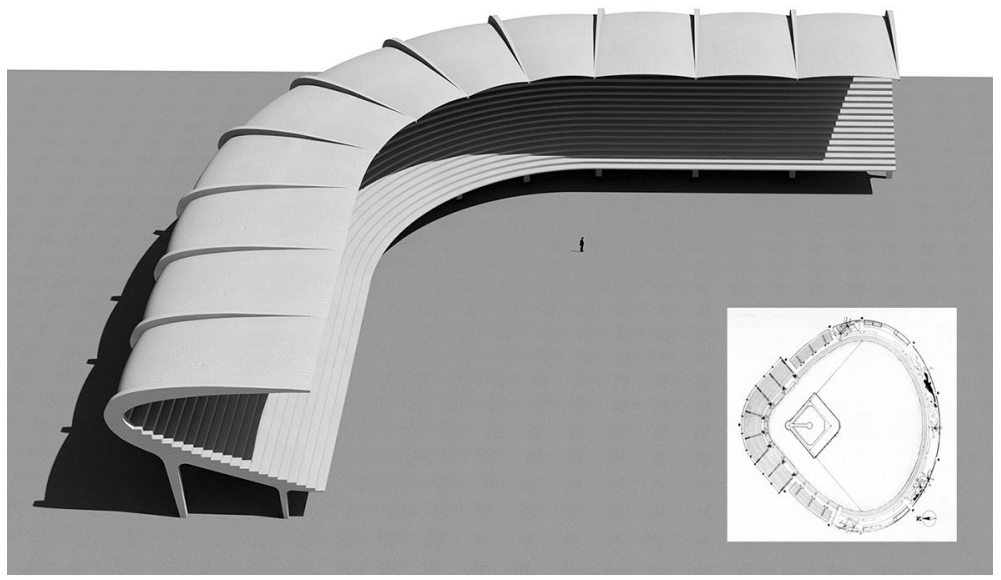

Fig. 2 Central stand three dimensional view. Source: Owen Development

Each of the 11 membranes forming the canopy is $5 \mathrm{~cm}$ thick and follows a parabolic outline in the longitudinal direction and a circular arch in transversal direction. Produced in situ, concrete compressive strength of $21 \mathrm{MPa}$ was used, contrasting with $14 \mathrm{MPa}$ for the foundations. Larger cantilever dimensions reach $16.59 \mathrm{~m}$, rising $14.27 \mathrm{~m}$ from the base, representing uncommon scales for concrete structures in Colombia at the time. A year after its opening, Architectural Record (1948) proclaimed its bold design:

So bold is the concept of this stadium, held by frames in the shape of a capital $\mathrm{C}$ or a standing sickle, that the editors obtained the approving opinions of New York engineers to anticipate possible objections.

The South American Architects declare that the North American tendency to find such structures "impractical" or "not quite safe" arises in reality from an Anglo-Saxon timidity in the face of bold plastic intervention.

Apart from confronting formal challenges with safety constraints, this publication more subtly questioned structural efficiency as explored by González Zuleta. A forced curve, where lower and top arms intersected within a $1.7 \mathrm{~m}$ by $0.60 \mathrm{~m}$ section, originated stress concentration requiring important reinforcing (Fig. 3) as commented on in the photographs:

Here may be seen the powerful reinforcing bars which take the tensional stress of C-curved vertical frames. Note also the preparation for coffering the thin canopy membrane ...

Under deflection action and to increase vault stiffness, González Zuleta defined five concrete arches (Fig. 4) having variable thickness and height (Tables 1,2). 


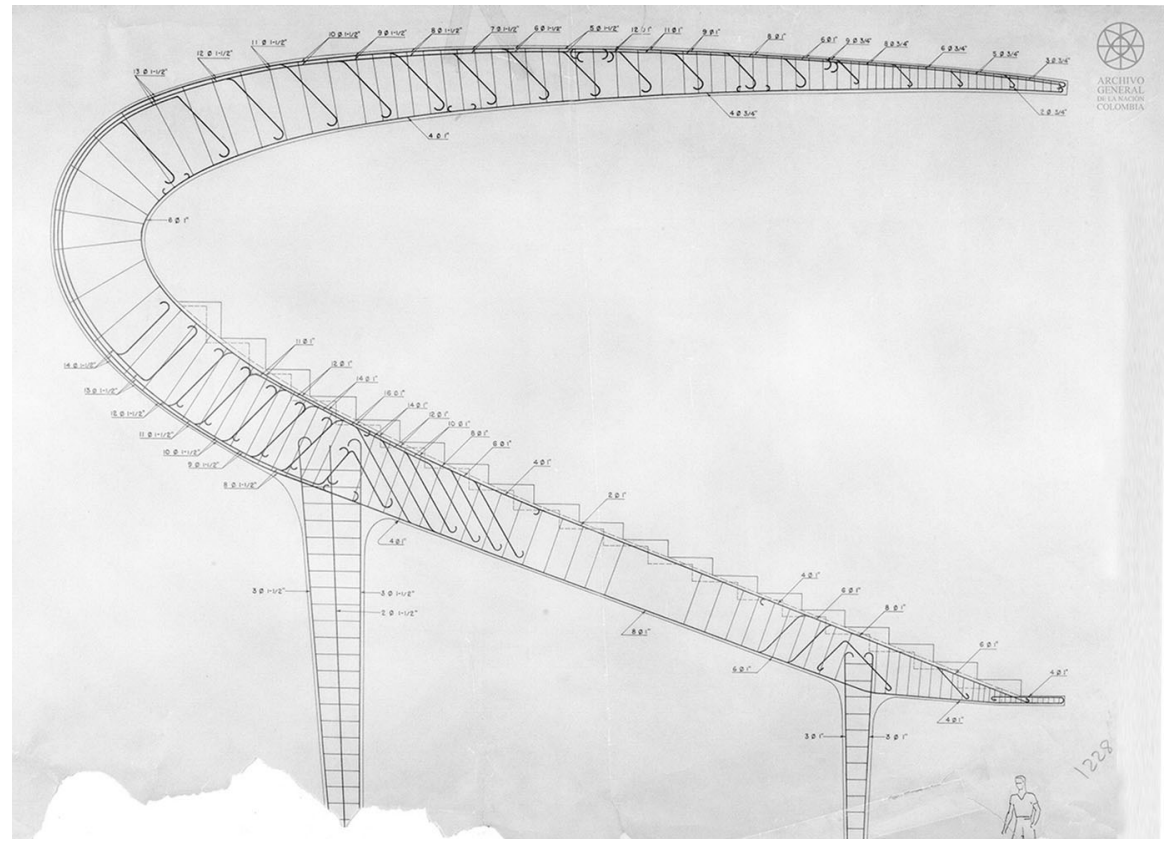

Fig. 3 Frame reinforcing. Source: Archivo General de la Nación, Colombia. Sección Mapas y Planos. Mapoteca Invías No. 1228

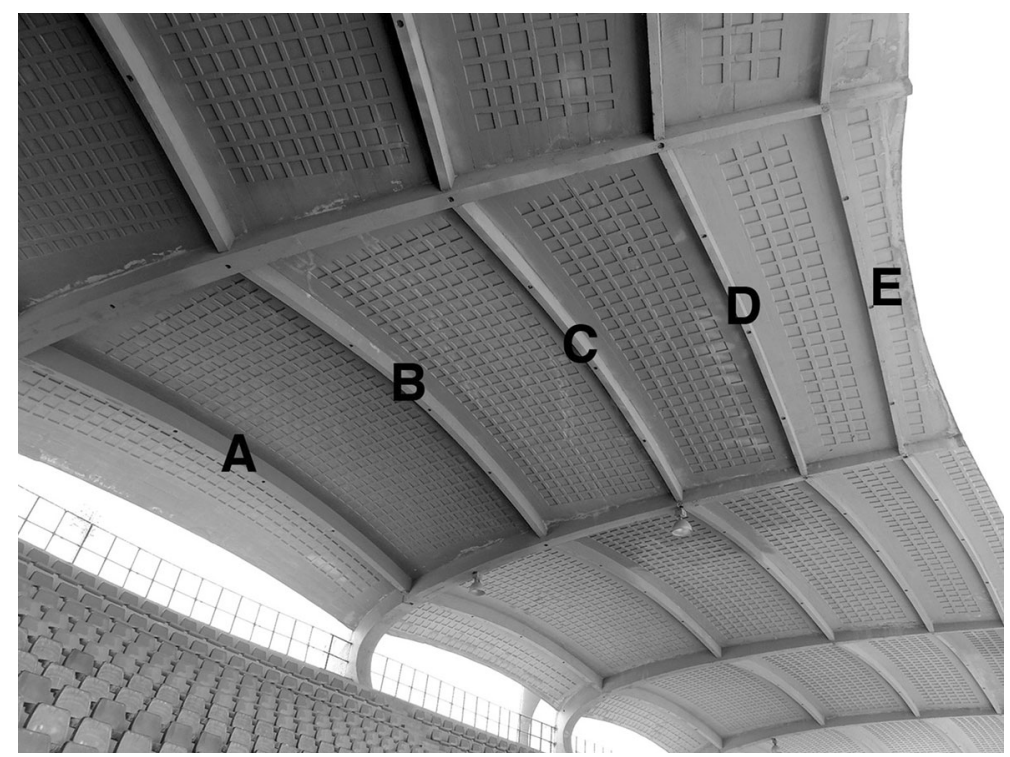

Fig. 4 Arches under the canopy shells 11 de Noviembre Stadium. Photography by the authors 
Table 1 Concrete arch dimensions under canopy shells confined within parallel frames (axis 1-4 and 9-12)

\begin{tabular}{llll}
\hline Arch type & Thickness, $\mathrm{cm}$ & Height, $\mathrm{cm}$ & Horizontal distance to arches, $\mathrm{m}$ \\
\hline A & 18.0 & 47.0 & To arch B: 5.00 \\
B & 16.5 & 39.6 & To arch C: 4.00 \\
C & 15.0 & 34.0 & To arch D: 3.00 \\
D & 13.5 & 29.6 & To arch E: 2.00 \\
E & 12.0 & 26.9 & To free edge: 1.00 \\
\hline
\end{tabular}

Table 2 Concrete arch dimensions located under canopy shells confined within non-parallel frames (axis 4-9)

\begin{tabular}{lcc}
\hline Arch type & Thickness, cm & Height, cm \\
\hline A & 21.0 & 47.0 \\
B & 18.0 & 39.6 \\
C & 15.0 & 34.0 \\
D & 12.0 & 29.6 \\
E & 9.0 & 26.9 \\
\hline
\end{tabular}

\section{Geometrical Layout of Structural Elements}

At first glance, the geometry and dimensions of the stadium's structural elements could be interpreted as being a result of the project's building constraints. However, a detailed analysis of the plans and sections suggests that, on the contrary, structural form came from a subtle and balanced geometrical exercise bidimensionally conceived and spatially superimposed.

How is the field and stand plan designed? In a baseball stadium the inner space or diamond is a 90 foot $(27.43 \mathrm{~m})$ square, where one of its corners (point $\mathrm{O}$ ) is the home plate where the batter acts as central focus during the game. Lines OK and $\mathrm{OW}$, or the foul lines, are 310 feet long. From point $\mathrm{O}$, straight lines $\mathrm{OL}$ and $\mathrm{OV}$ are 370 feet long while segments $\mathrm{OM}$ and $\mathrm{OM}$ are 400 feet long and are spaced at an 18-degree angle forming the so-called gardens. From points $\mathrm{L}$ and $\mathrm{V}$, perpendiculars to OW and OK define points R and P. Segments OR and OP are $32.19 \mathrm{~m}$ in length, corresponding to structural frame 1-14 and 9-12 spacing. On the other hand, structural axes 5-6-7-8 converging at point $\mathrm{O}$ are $18^{\circ}$ apart. It can be concluded that the spacing of the structural axes, in parallel and radial positions, are all defined as a result of baseball field regulatory lines (Figs. 5, 6).

After the plan geometry definition, the concrete frame geometry is explored (Fig. 7). The first step is to define a horizontal line SOU rising $11.248 \mathrm{~m}$ above the building base. Related to the segment SOU two rectangular coordinate systems are proposed: first with $u$ and $v$ as axes and second with $x$ and $y$ as axes. The $x$-axis in inclined 15\% under SOU, as optimal vision angle for spectators (Fig. 8). Above this last coordinate system, a parabola is defined with the equation: 


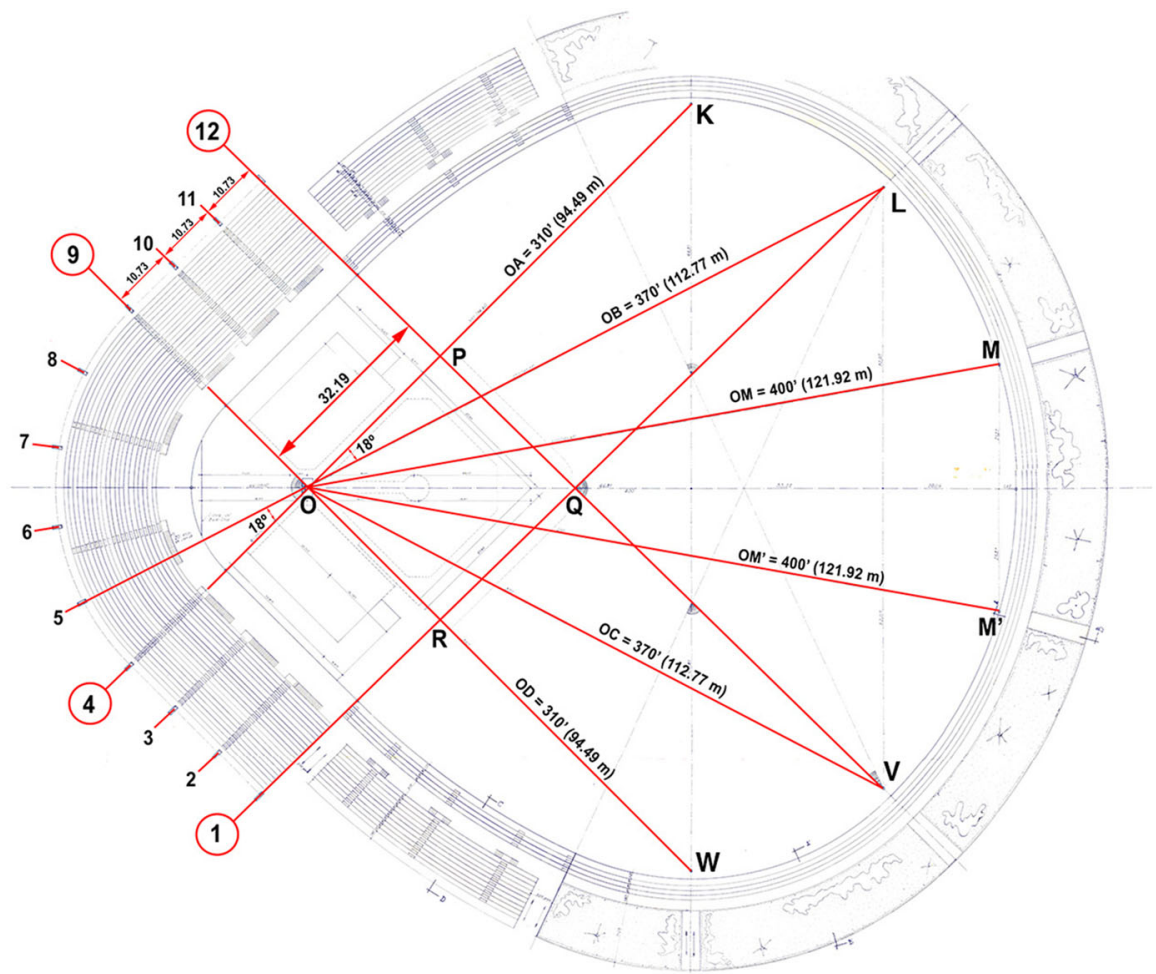

Fig. 5 Relationships among regulatory field lines and building structural axes. Source: authors work upon project plan in Archivo General de la Nación, Colombia. Sección Mapas y Planos. Mapoteca Invías No. 1937

$$
y=1.69 x^{2}
$$

This same parabola, related to the $o-u-v$ system corresponds to the expression:

$$
0.0225 u^{2}+0.3 u v-1.708906 u+0.256336 v=0
$$

Once the parabola equation determining the frame interior curve layout has been determined, it is necessary to find a method to define the exterior curve SNR as locus of points located at $h$ height upon OM parabola. To do this, González Zuleta proposed the equation:

$$
h=8.5\left(20-u^{\prime}\right) \mathrm{cm}
$$

where $u^{\prime}$ is the abscissa above the horizontal straight line SOU. Additionally, $P=-0.407 \mathrm{~m}$ is taken related to $\mathrm{O}$ as origin and measuring along the perpendicular to parabola OM in the point considered as shown in Fig. 6. Additionally, the superior cantilever beam width is obtained from:

$$
b=3\left(20-u^{\prime \prime}\right) \mathrm{cm}
$$




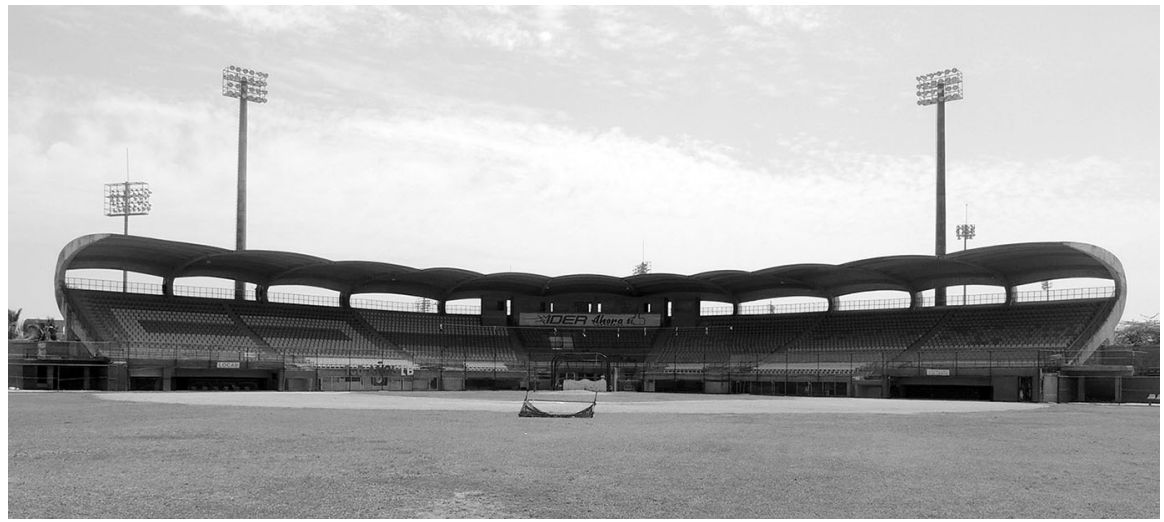

Fig. 6 Covered stand from the field. Photography by the authors

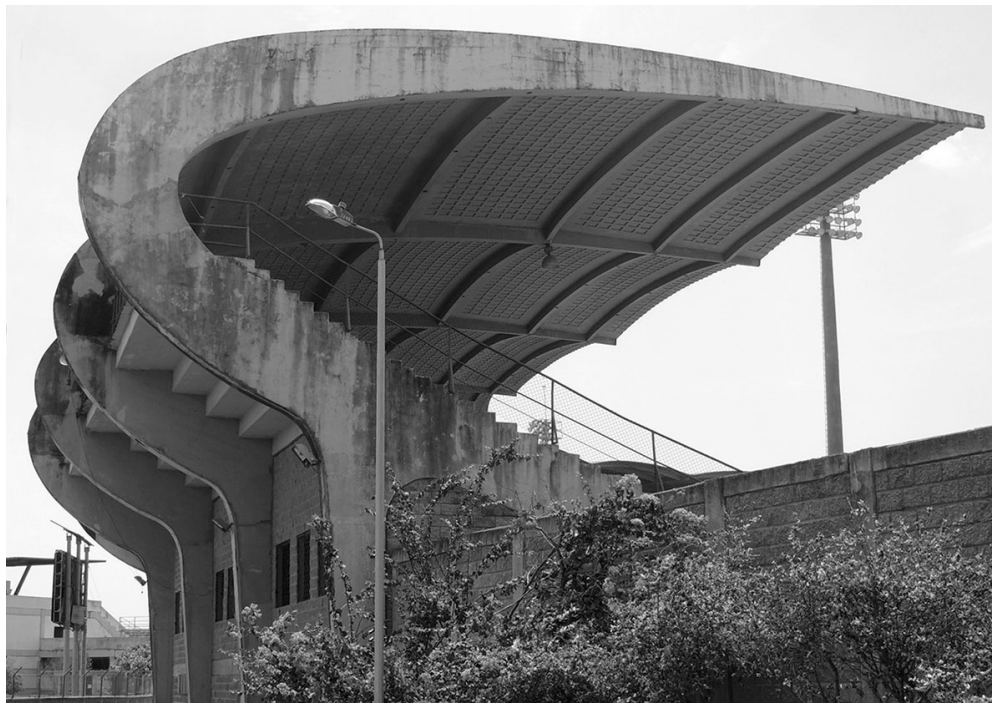

Fig. 7 External C Frame Vista structural axis 1. Photography by the authors

For this equation, the abscissa will be measured from point $\mathrm{O}$ along the horizontal to the parabola normal plan. From point B in the BSL direction, the width is constant and equal to $0.60 \mathrm{~m}$.

Finally, to establish the frame lower layout, the curve SL is the locus for $h_{1}$ distances taking $Q=-1.407$ as the origin relative to $\mathrm{O}$ according to Table 3 . $h_{1}$ distances are measured along the normal to the OA parabola traced from exterior points $d, e, f$ and $g$. The distance between $\mathrm{P}$ and $\mathrm{Q}$ is $1.0 \mathrm{~m}$.

Once the plan layout and frame sections have been solved, the shell curvature geometry needs to be determined. To do this, González Zuleta used a circular arch whose radius is always based on the free spacing $\mathrm{L}$ for concrete $\operatorname{arches} \mathrm{A}, \mathrm{B}, \mathrm{C}, \mathrm{D}$ and $\mathrm{E}$ shown in Fig. 4. In all cases $\mathrm{L}$ is variable, as are the frame widths, $b$. 


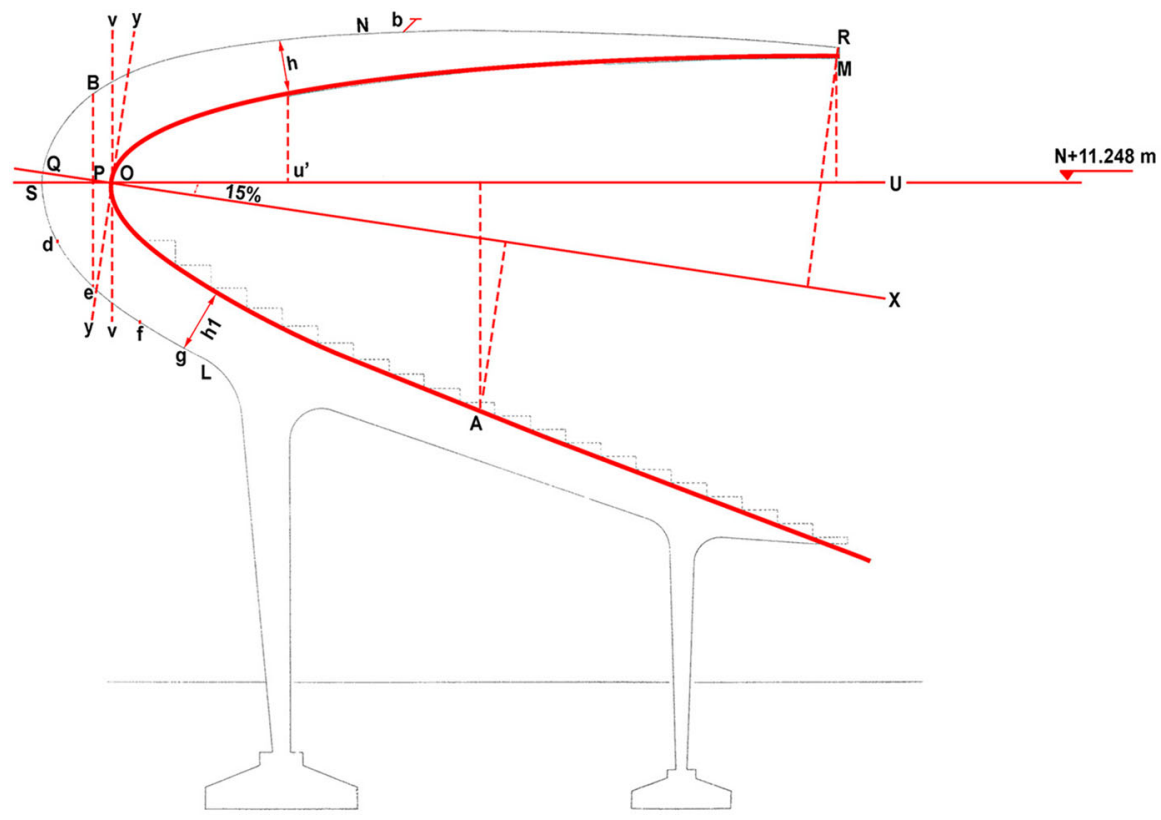

Fig. 8 Frame section parabolic layout. Source: authors work upon project plans in Archivo General de la Nación, Colombia. Sección Mapas y Planos. Mapoteca Invías No. 1937

Table 3 Width $h_{1}$ as function of abscissa $u$ on SL curve

\begin{tabular}{lc}
\hline$u$ & $h_{1}$ \\
\hline 0 & 1.66 \\
1 & 1.62 \\
2 & 1.58 \\
3 & 1.54 \\
\hline
\end{tabular}

For the confined arches between parallel frames (Fig. 9) as well as the confined arches between the radial frames (Fig. 10), the equation for the radius is:

$$
R=2.5 L
$$

The final result of this geometrical relationship is a set of 11 dual curvature vaults. In one direction they correspond to a parabolic layout, in the other they correspond to a circular form (Fig. 11). Inferior ceiling panels (cassetone), which result from the building technique and the need for a lighter dead load, will enrich the final project.

Lastly, but significantly, the integrated stand and canopy forms follow a rational layout coming from vertical isoptical lines to provide full visibility towards the field, thus generating a continuous parabolic silhouette whose geometrical conception and application was already discussed. 


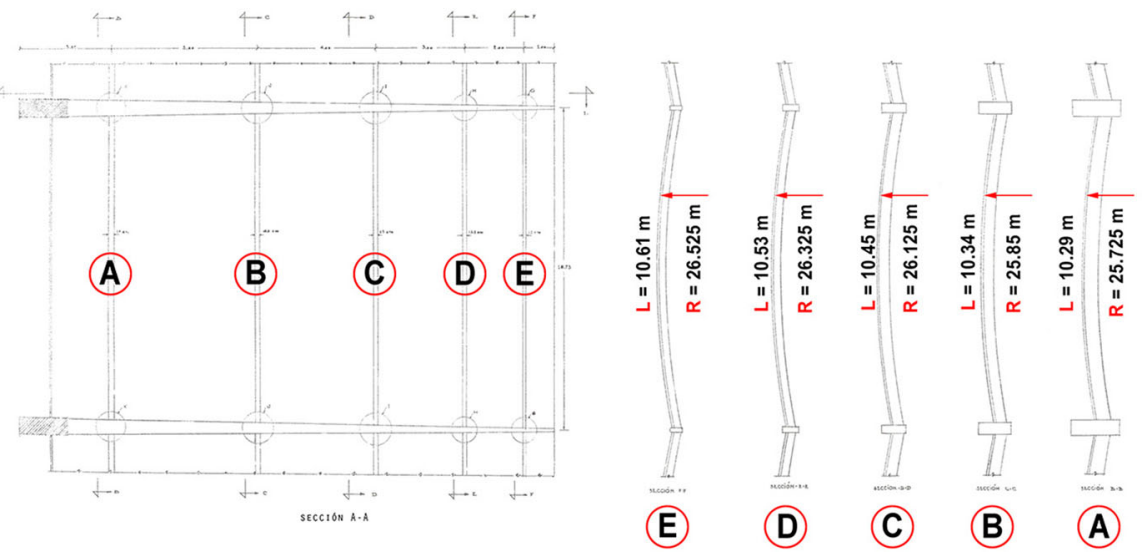

Fig. 9 Inferior parallel frame confined vault layout. Source: authors work upon project plans in Archivo General de la Nación, Colombia. Sección Mapas y Planos. Mapoteca Invías No. 1937
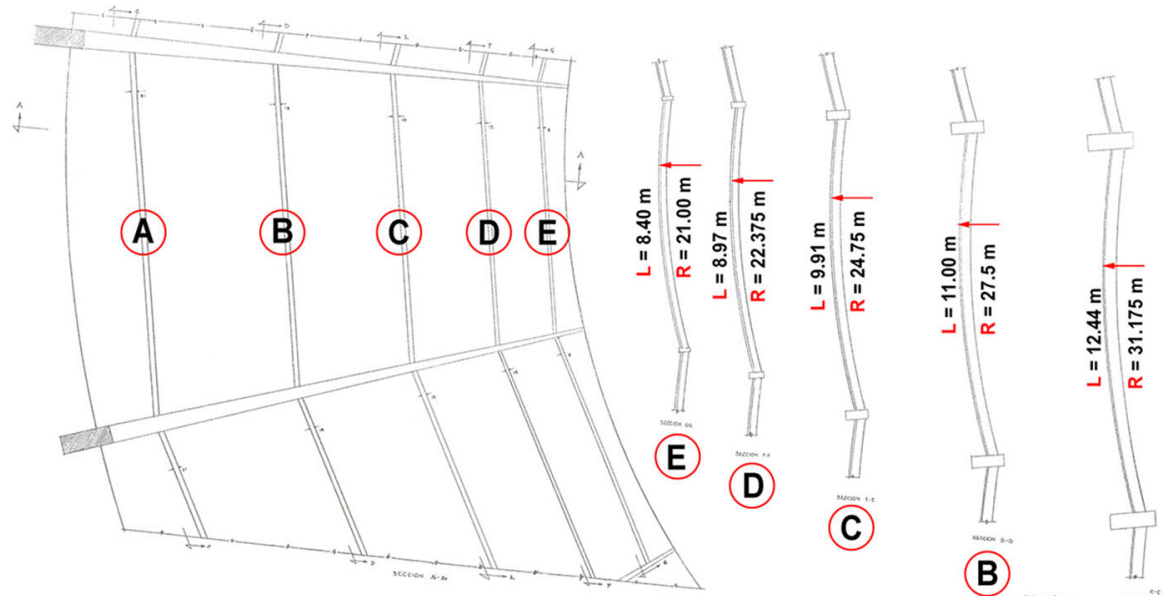

(A)

Fig. 10 Confined vaults between parallel frames layout. Source: authors work upon Project plans in Archivo General de la Nación, Colombia. Sección Mapas y Planos. Mapoteca Invías No. 939

\section{Around the Building Process}

As a consequence of the described geometrical process it became possible to count on a detailed working plan to guide on-site operations (Fig. 12) where precise dimensioning is available for coordinates, thus enabling carpenters to construct their formworks (Fig. 13). Geometry proves the building essence and guide.

It is also interesting to study the way in which González Zuleta reduces the weight of the vaults. 


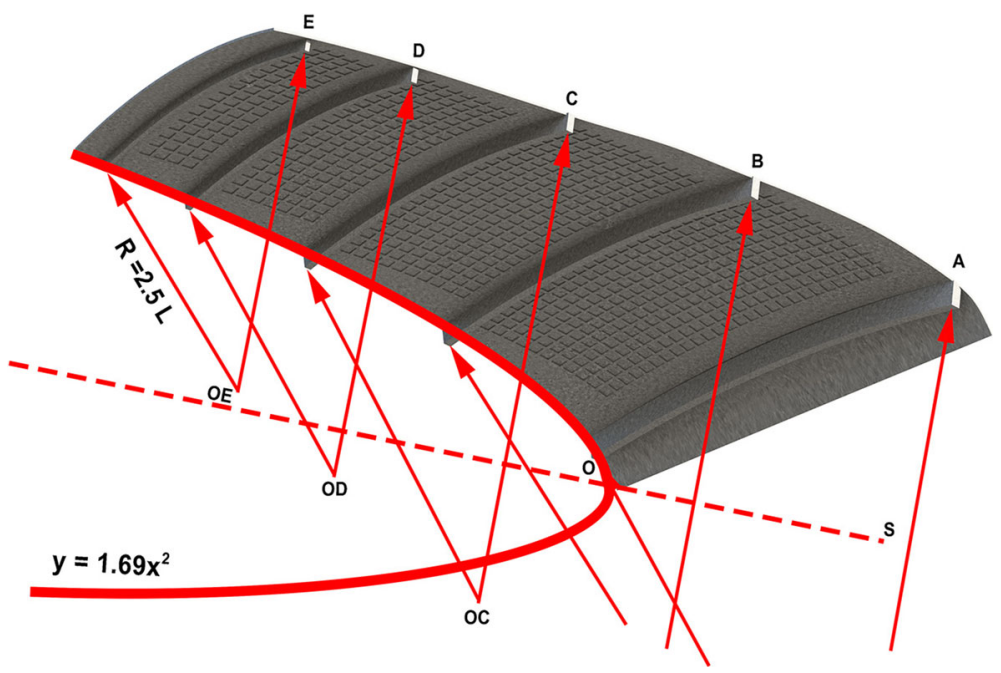

Fig. 11 Tridimensional vault inferior view. Source: own development

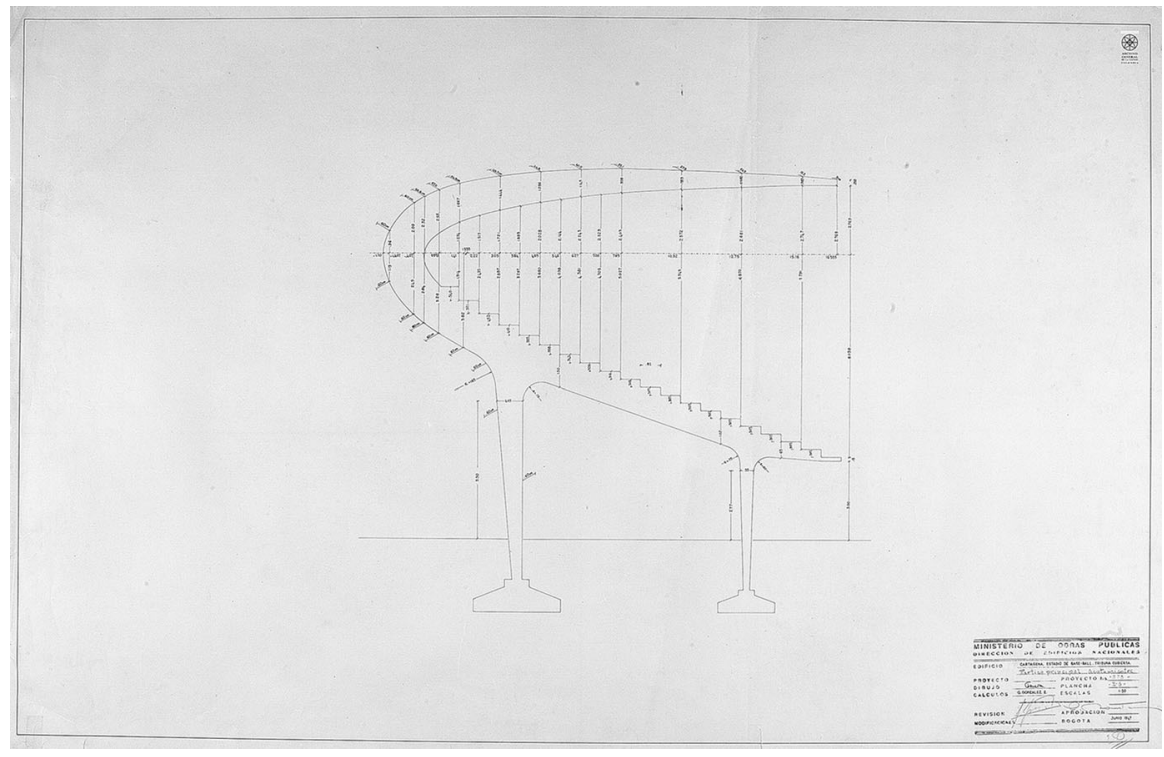

Fig. 12 Vault formwork coordinate system. Source: Archivo General de la Nación, Colombia. Sección Mapas y Planos. Mapoteca Invías No. 250

Confined vaults within parallel frames have " $1 / 4$ " steel rebar within a grid on the inferior face forming solid ribs $8 \mathrm{~cm}$ wide whereas residual spaces are defined with flat hollow clay units $25 \times 25 \mathrm{~cm}$ (Fig. 14). For vaults that are confined between radial frames a cast-in-place cassetone pattern is designed substituting clay pieces. It appears that González Zuleta's design included both types to be tested under real construction conditions. 


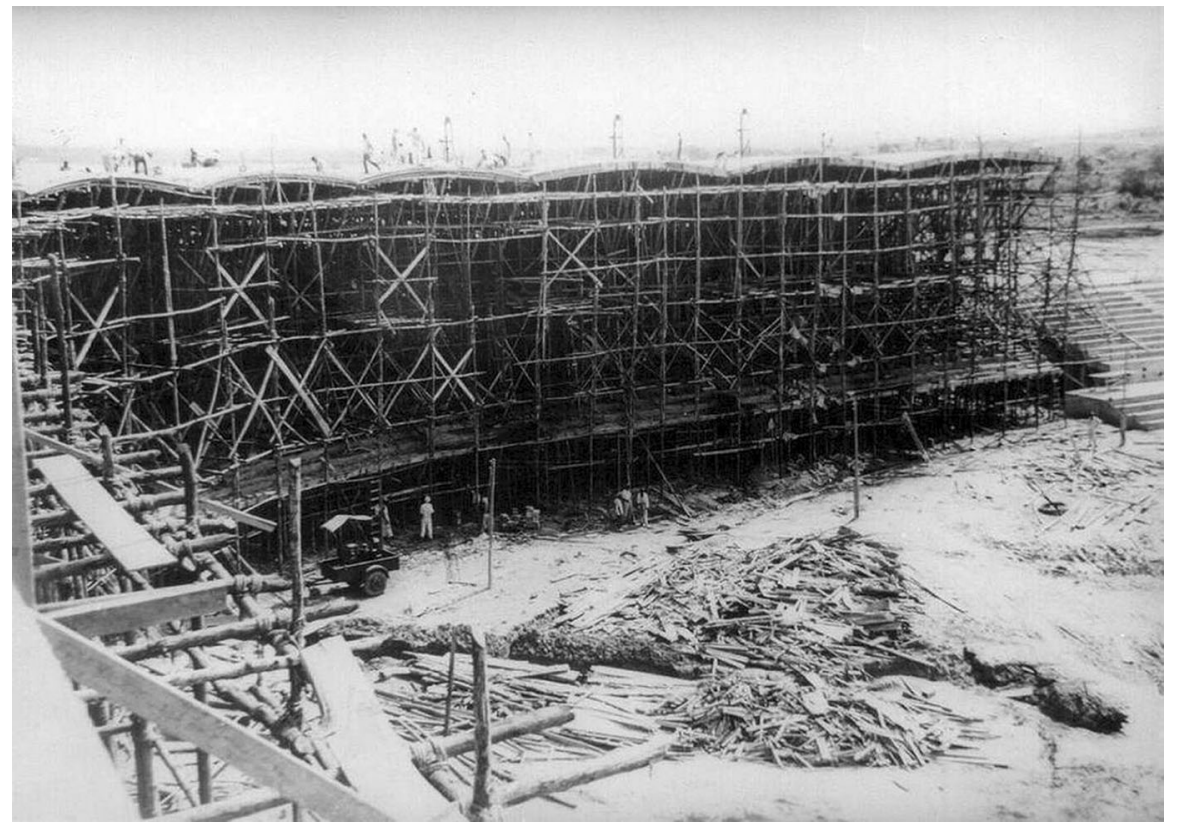

Fig. 13 Vault formwork 1947. Source: particular archive

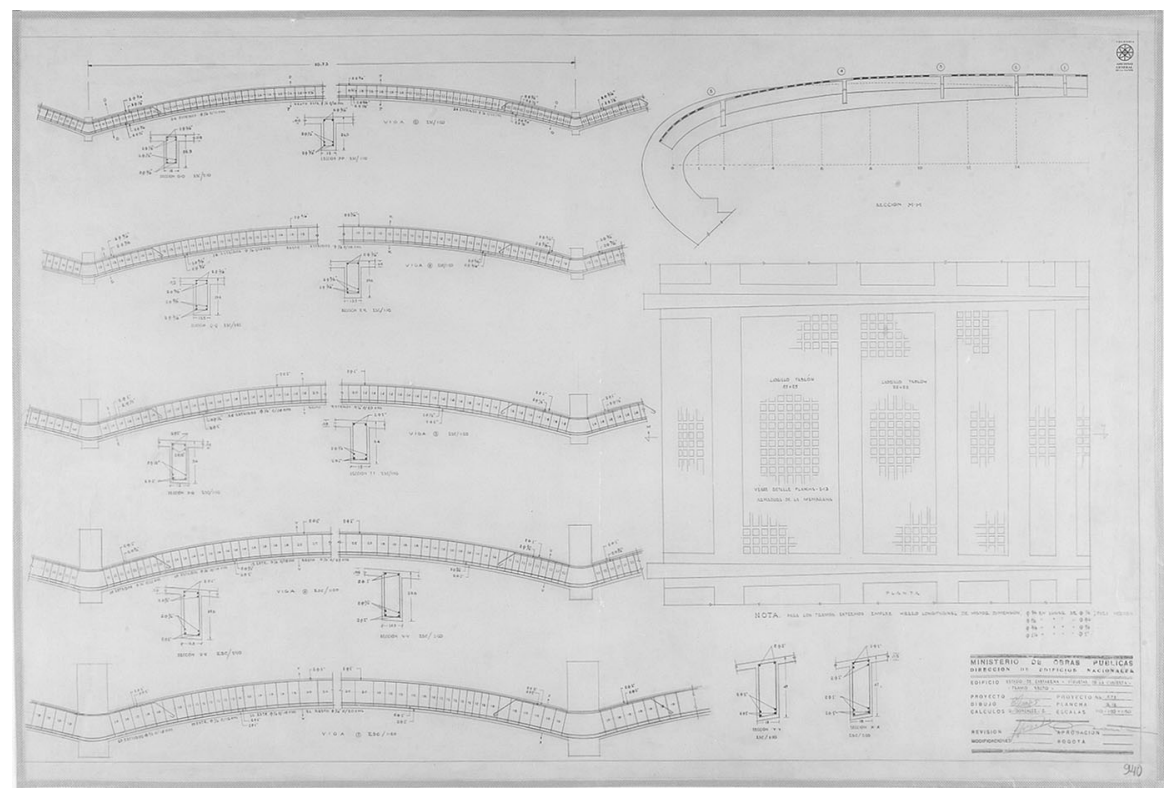

Fig. 14 Confined vault between parallel frames cassetone detailing. Source: Archivo General de la Nación, Colombia. Sección Mapas y Planos. Mapoteca Invías No. 940 


\section{Other González Zuleta Works}

In his free professional practice as a civil engineer, González Zuleta worked after 1947 alongside recognized Colombian architects in Bogota and other Colombian cities, acting not only as a designer but also managing building tasks where he acted as a master builder, integrating design and building (Vargas 2009).

From 1950 to 1955 he collaborated with architect Antonio Mesa Jaramillo in Medellin. This team built two churches with thin ceramic shell roofing: Virgen de Fátima (1950) (Fig. 15) and UPB temple (1955). They also participated in building the local football stadium stands.

Religious projects reappear in González Zuleta works. In 1952 he designed the Usaquén church for architects Luis David Vásquez and Dairo Cárdenas, with a skeleton of concrete arches and thin reinforced ceramic membranes. In 1953 he designed the Gimnasio Moderno (Fig. 16) and Fatima churches in Bogota for architect Juvenal Moya, using the same methods and materials. In 1954 he designed similar churches for Cisneros and San Joaquin in the State of Antioquia.

In 1954 González Zuleta collaborated with the Michigan-graduated Colombian architects Francisco Pizano and Roberto Rodríguez on a supermarket in Bogotá. The architectural point of departure, within an irregular plot, was to have a great squared hall vaulted in two directions with a reinforced hollow clay brick membrane supported by four inclined columns spaced $22.5 \mathrm{~m}$ apart. Hollow bricks $5 \mathrm{~cm}$ thick were used for the roof design, which included eight skylight openings (Fig. 17). This project had as a previous source Co-Op and Aruṕs Brynmawr Rubber Factory (1948-52), now demolished, based on nine laminar concrete cupulae under the $Z-D$ system (May 2015).

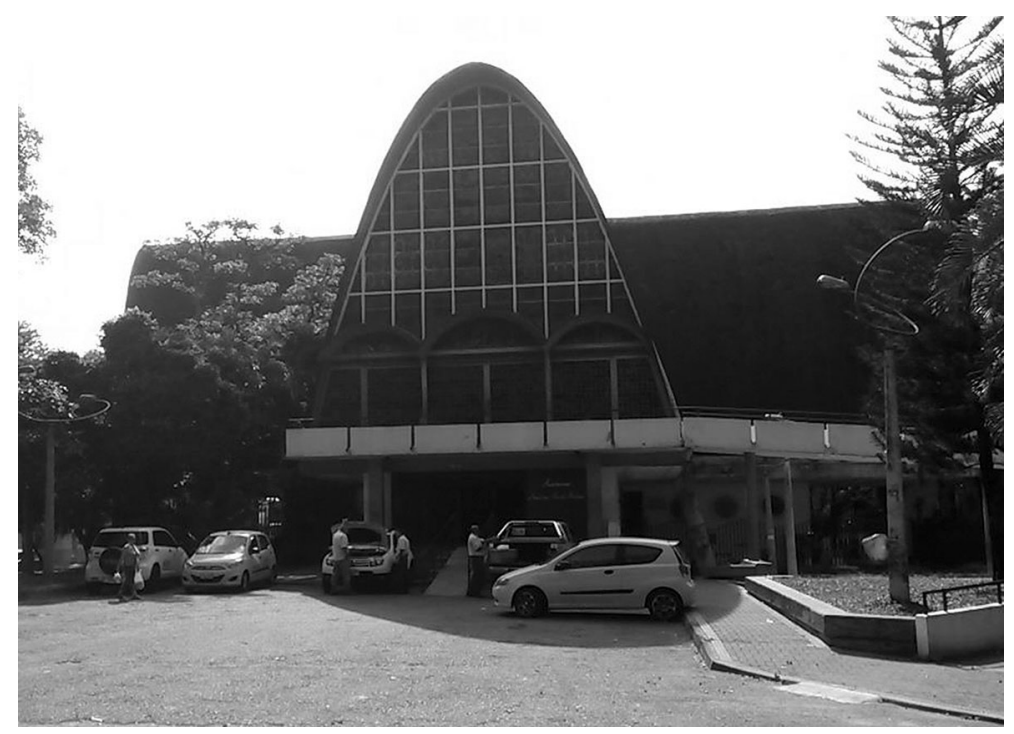

Fig. 15 Virgen de Fátima Church Medellín (1950). Photography by the authors 


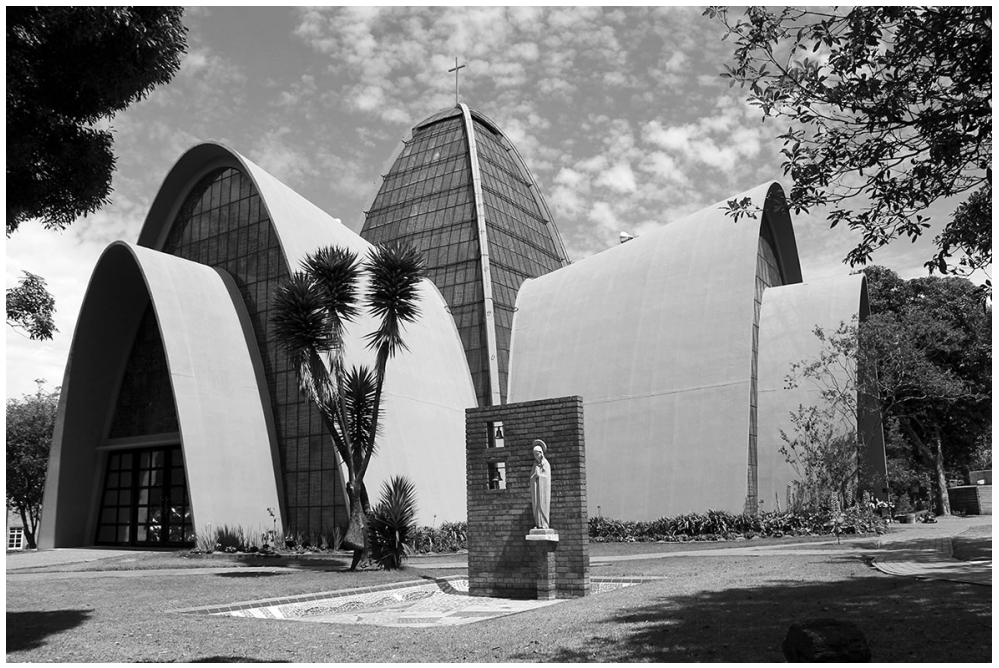

Fig. 16 Gimnasio Moderno Church, Bogotá (1953). Photography by the authors

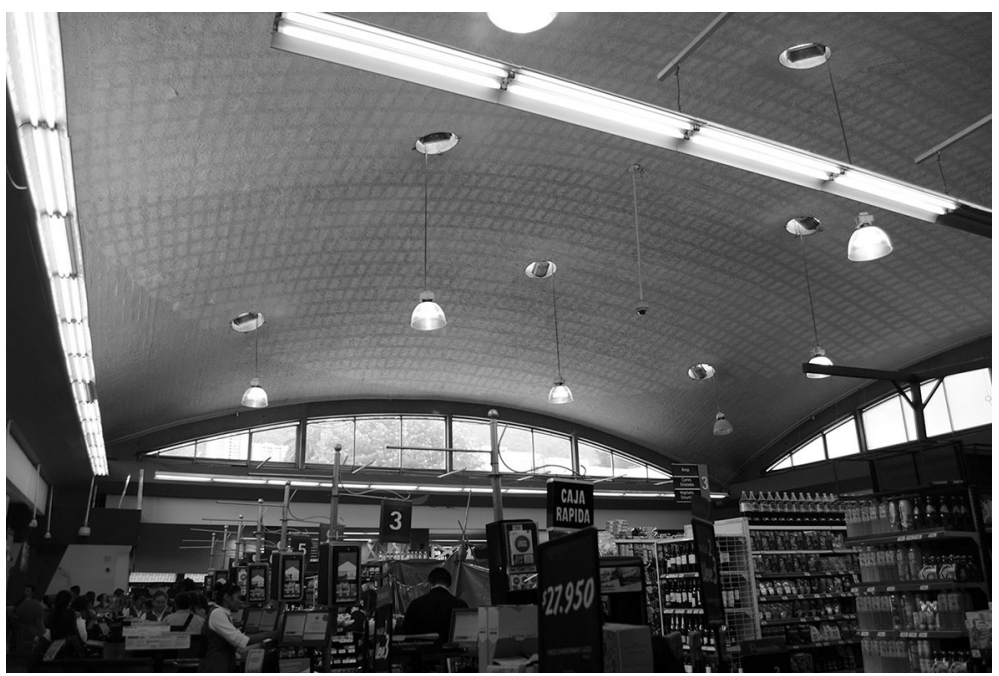

Fig. 17 Rayo Market Hall, Bogotá (1954). Photography by the authors

González Zuleta's designs for sport facilities were particularly innovative, working in its stands and roofing systems. In 1955 his Bogotá Jockey Club showed a clear reference to Eduardo Torroja's work, proposing a very light cantilever reaching $23 \mathrm{~m}$ and showing $5 \mathrm{~cm}$ vaulting parallel to the stands (Fig. 18). According to the project data published in Proa (1952), a $20 \mathrm{MPa}$ reinforced concrete structure supported $27 \mathrm{MPa}$ vaulting using Chilean steel rebar under a building site headed by engineer Luis Mora within schedule. 


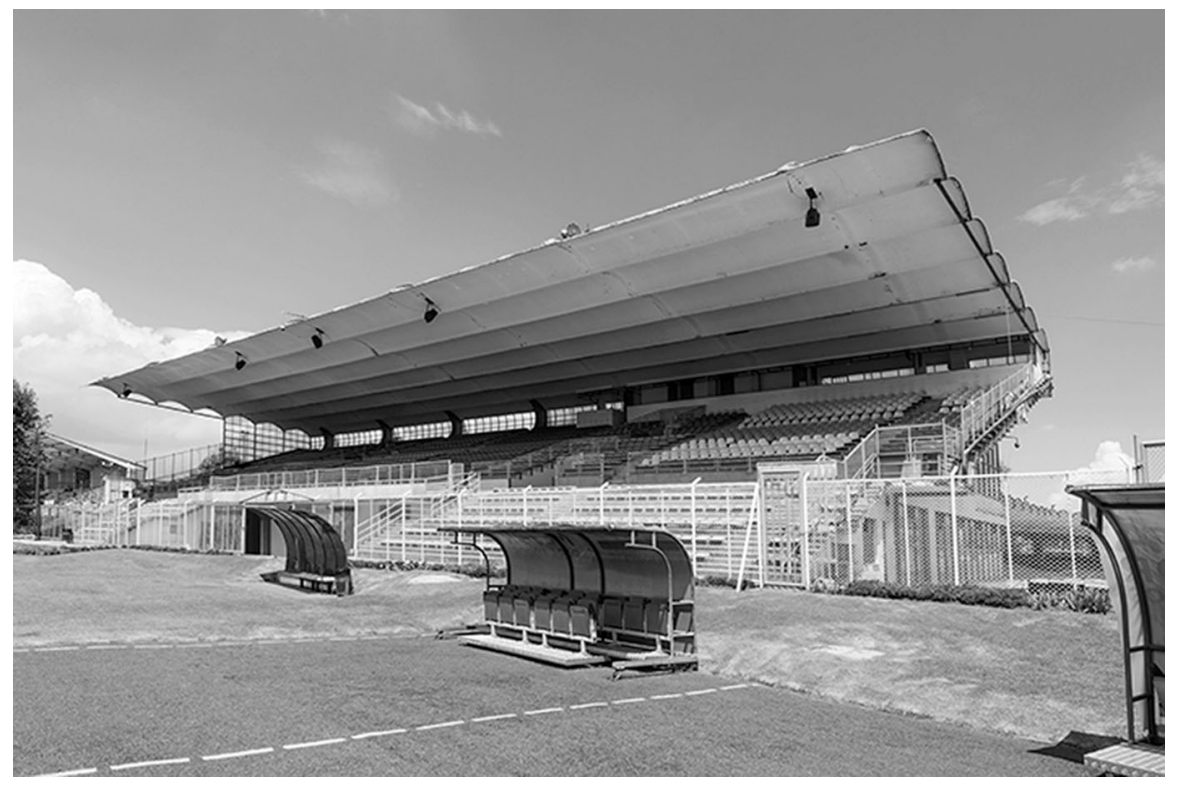

Fig. 18 Jockey Club Bogotá (1955). Photography by the authors

In his large and dynamic practice (Vargas 2009) González Zuleta developed designs for infrastructure including harbours and bridges, industrial, commercial and institutional projects that won several national prizes for their structural excellence.

\section{Concluding Remarks}

Cartagena de Indias Baseball Stadium's geometrical dimensioning, as formed by a set of concrete $\mathrm{C}$ frames supporting light reinforced ceramic shells, is not only the result of structural design but a product of an elaborate geometrical exploration and prescriptions to have thin and buildable structural sections. The mathematical tools developed to confirm and execute structural works serves the early and minute exploration of its components going across bidimensional definitions. These guides were a response for a building process to be proofed for common construction workers within severe time constraints. Lessons learned from this work would mark design and building practices in Colombian architecture for years to come.

\section{References}

Arango, Silvia. 1989. Historia de la arquitectura colombiana. Bogotá: Universidad Nacional de Colombia.

Architectural Record. 1948. Pitching a Bold Curve in Concrete: Baseball Stadium at Cartagena, Colombia, South America. Architectural Record 104 (1): 88-93. 
Bonelly, Rafael. 1942. Bóvedas membranas. Ingeniería y Arquitectura, 40 (1): 18-21.

Cassi Ramelli, Antonio. 1950. Documenti di Architettura. Composizione e Tecnica Moderna. Milano: Antonio Vallardi.

Cornelissen, Henry. 1944. Bóvedas membranas de sección circular. Ingeniería y Arquitectura 59 (1): 5-10.

Guerra, Leopoldo. 1941a. Resistencia probable de un concreto a los veintiocho días. Ingeniería y Arquitectura 25 (1): 26-28.

Guerra, Leopoldo. 1941b. Ensayo del cemento producido por la Fábrica del Valle "Cemento Conquistador". Ingeniería y Arquitectura 26 (1): 9-10.

Informes de la Construcción. 1949. Tribuna de hormigón armado (Pitching a Bold Curve in Concrete) estadio de "baseball” en Cartagena, Colombia. Informes de la Construcción 7 (1): 152-156.

May, Roland. 2015. Shell Sellers: the International Dissemination of the Zeiss-Dywidag System, 1923-1939. In: Proceedings of the 5th International Congress on Construction History (Chicago, July 2015), ed. B. Bowen, D. Friedman, T. Leslie, T. and J. Ochsendorf, J., 557-564. Chicago: Construction History Society of America.

Paredes, Luis and Alfonso Garzón. 1941. Encofrados en ladrillo hueco. Ingeniería y Arquitectura 27 (1): 31-32.

Proa. 1952. El nuevo hipódromo de Bogotá. Proa 60 (1): 20-23.

Vargas, Hernando. 2009. El desarrollo de la edificación en concreto armado en Colombia: el caso de los pioneros Domenico Parma y Guillermo González Zuleta. Revista DeArquitectura (4), 64-75.

Vargas, Hernando and Jorge Galindo. 2015. The Construction of Thin Concrete Shell Roofs in Colombia During the First Half of the 20th Century: The Works of Guillermo González Zuleta (1916-1995). In: Proceedings of the 5th International Congress on Construction History (Chicago, July 2015), ed. B. Bowen, D. Friedman, T. Leslie, T. and J. Ochsendorf, J., 525-533 Chicago: Construction History Society of America.

Vargas, Hernando and Juan Pablo Ortega. 2008. 100 años del cemento en Colombia: Notas sobre su origen. Revista Noticreto 100 (1): 46-61.

Zietzschmann, Einrich. 1952. Stadionbau gestern und heute. Schweizerische Bauzeitung 70 (1): 353-359.

Jorge Galindo Díaz B. A. in Architecture, Universidad del Valle, 1991. Doctor of Architecture, Escuela Técnica Superior de Arquitectura de Barcelona, 1996. Senior Lecturer in the School of Architecture and Urbanism at the Universidad Nacional de Colombia. Researcher in subjects of History of the Technique and History of Construction. Author of numerous articles and papers at international events.

Hernando Vargas Caicedo B. S. in Civil Engineering, Universidad de los Andes, 1971. Master in City Planning, MCP, and Science Master in Architecture Studies S.M.Arch.S, Massachusetts Institute of Technology MIT, 1987. Full-time Professor Titular, Universidad de los Andes, Department of Architecture, Department of Civil and Environmental Engineering, 2002-2011. Coordinator of Construction Engineering and Management Master's Program, 2008-present. Historia de la Técnica Constructiva en Colombia, Research Group Director 2002-present. 